\title{
Крестьянские устные повести: опыт дискурсивного чтения ${ }^{1}$
}

\author{
В.Г. ВИНОГРАДСКИЙ*
}

\begin{abstract}
*Валерий Георгиевич Виноградский - доктор философских наук, ведущий научный сотрудник, Центр аграрных исследований Российской академии народного хозяйства и государственной службы при Президенте Российской Федерации. Адрес: 119571, Москва, проспект Вернадского, 82, стр. 1. E-mail: vgrape47@yandex.ru
\end{abstract}

Цитирование: Виноградский В.Г. (2018) Крестьянские устные повести: опыт дискурсивного чтения // Мир России. Т. 27. № 1. С. 90-113. DOI: 10.17323/1811-038X-2018-27-1-90-113

В статье содержится попьтка демонстрации и дискурсивного прочтения крестьянских устных историй. Как выглядит крестьянская повседневность в ее дискурсивном измерении? В чем заключается специфичность «голосов снизу» как дискурсивных форматов? Можно ли, вслушиваясь в крестьянскую речь, полнее осознать образ и устройство деревенского мира, а также предугадать перспективы его исторической эволюичи? Чему может научить исследователя систематическое наблюдение трансформации крестьянских дискурсивных практик? Статья содержит в себе опыт аналитического рассмотрения природы крестьянских дискурсивных форматов. В ней также представлен один из нарративов, записанных в ходе Первого полевого крестьяноведческого проекта Теодора Шанина (1990-1994 г2.), сопровождаемый попутными авторскими комментариями, сосредоточенными на выявлении специфики и дискурсивньх свойств «голосов снизу».

Ключевые слова: дискурс, дискурсивные практики, стиль, устные истории, крестьянские миры, социология села, сельская повседневность, эволюция дискурсивных практик

1 Статья подготовлена при поддержке РФФИ, проект «”Голоса снизу”: эволюция крестьянских дискурсивных практик» (№ 15-03-00004). 


\section{Введение}

«Чуткость русского мира к слову была и остается историческим событием, размах которого мы сейчас измерить пока не можем. Большей частью мы этого - насколько пространство, в котором мы движемся, это пространство слова - просто не замечаем» [Бибихин 2009, с. 305]. В этих словах - урок высшей наблюдательности. Замечать слово - это значит метить базовые контуры бытия, видеть его ориентиры, ведь само бытие проектируется, вычерчивается, хранится словом. Попытаемся всмотреться в пространство народного слова, вслушаться в «голоса снизу». Я знаком с ними не понаслышке, как ни двусмысленно здесь это определительное наречие. Начав в 1990 г. записывать крестьянские повести, я убедился - человеческие голоса не только слышатся. Они еще и касаются нас, трогают, задевают. Понимать язык - значит и слышать, и воочию наблюдать «пространство слова». Суровая материя крестьянской повседневности, где напрягаются в житейских заботах и созерцательно разгуливают ее творцы и участники, аккуратно снята с магнитной ленты. Попробую проделать опыт дискурсивного чтения одного из крестьянских голосов.

Крестьянские устные повести всякий раз демонстрируют образ посильно укрощенной действительности, изворотливо выскальзывающей из железных клещей напористой индустриальной распорядительности. Она инстинктивно уклоняется и от приструнивающих политических натисков; она не теряется в тормозящей оробелости, но и почти никогда не лезет на рожон - «хоть не пышно, да затишно»; «некрасиво, да спасибо». Народный язык, развернутый в дискурсе крестьянской повседневности, - это непродуваемый, бережно-укрывающий «дом бытия» ${ }^{2}$. Этот язык - орудие ненасильственной, уступающей приспособляемости к давлению жестко-принудительных жизненных ситуаций. Ну, не толково ли: «кряхти да гнись: упрешься - переломишься»; «чем маяться, так лучше отступиться»; «не торопься, Окся, еще Паранька в девках»? Крестьянские дискурсивные практики отражают неиссякаемую, смиренную надежду - «не плачься, что ночь студена: ободняет, так обогреет»; «счастье придет - и на печи найдет».

Здесь открывается основной, животворный и в то же время нежалостливый «яростный мир» ${ }^{3}$. Как бы там ни было, из деревенских миров выходишь в иные бытийные пространства уже другим, чем был прежде: не столько информированным и поумневшим, сколько очарованным и проветренным.

\section{Дискурсивная разметка крестьянских миров}

Крестьянские устные повести - это речевые продукты, производимые в крестьянских мирах. Чикагский антрополог и социолог Роберт Редфилд проницательно назвал крестьян «нерассуждающим большинством» (largely unreflective many) [Redfield 1956, p. 60]. Характеристика точная, но устаревшая, и не потому, что

2 Хайдеггер М. (1997) Бытие и время / Пер. с нем. В.В. Бибихина. М.: Ad Marginem.

3 Платонов А.П. (2012) В прекрасном и яростном мире. М.: Эксмо. 
«нерассуждающее», а потому что крестьяне уже не «большинство». Но изменилось ли с течением времени крестьянское «нерассуждение»? Нет. Крестьяне по-прежнему в определенном смысле не рассуждают. Но верно ли, что они не производят дискурс как особую инструментально-логическую конструкцию, позволяющую обрести и выверить равновесие между субъектом и объектом, между индивидом и обществом, между историей и биографией? Как можно говорить именно о крестьянских дискурсах? Примечательно, что из почти двухсот терминологических связок, имеющих в качестве сказуемого понятие «дискурс» и зафиксированных в словнике энциклопедии «Дискурсология» [Дискурсология 2009], не нашлось места для «крестьянского дискурса». Это ожидаемо, поскольку вряд ли среди агональных, артхаусных, байкерских, брутальных, гастрономических, карнавальных, меланхолических, плутовских, психоделических, сардонических, ювенальных и еще более замысловатых, числом свыше ста пятидесяти, разновидностей дискурса может отыскаться местечко для дискурса крестьянского. Почему? Вероятно, потому что имеет место установка, в соответствии с которой дискурс - это речевая практика избранных. Дискурс как рассуждение может обретаться лишь в интеллектуально искушенных, специализированных социумах. Такой установке способствует и сам термин «дискурс»- иноземное, сугубо научно звучащее. Так ли это? Что есть дискурс как понятие?

Исследователи, анализирующие представление о дискурсе, отталкиваются от понятия «текст». Это продуктивный аналитический ход. Дискурс - это текст, но такой, который «всегда с тобой». «Текст» есть нечто такое, что можно бросить и забыть. Как, скажем, актер или докладчик может забыть/потерять текст роли или выступления. Но дискурс не забудешь, потому что он постоянно в тебе. Потому что он актуален в том коммуникационном мире, где ты свой, а не чужой; где ты в своей - родной, исхоженной, изведанной - социолингвистической среде; где у тебя нет нужды что-то старательно обосновывать, доказывать и логически выводить. Прав лингвист В.3. Демьянков, утверждавший, что дискурс «<..> концентрируется вокруг некоторого опорного концепта, создает общий контекст, описывающий действующие лица, объекты, обстоятельства, времена, поступки и т.П., определяясь не столько последовательностью предложений, сколько тем общим для создающего дискурс и его интерпретатора миром, который “строится” по ходу развертывания дискурса» [Демьянков 2007, с. 86-95].

Чем определяется «крестьянский дискурс»? Тем опорным контекстом, имя которому «крестьянский мир»: крестьянин прикреплен к земле и к соседям, к ближайшей округе, к своей деревне, станице, хутору. У него одна родина - «малая»; у него нет иных, чем традиционное природопользование, источников доходов, нет второго жилища. Элементы деревенского микромира сочтены, они неподвижны, устойчивы и незамысловаты. Примечательно, что с помощью Google Earth мы увидим лишь несколько порядков деревенских изб и полоску центрального прогона, а позади домов - контуры огородов, сенокосов, тропинки к речкам, колодцам, родникам. И это все! В то время как пространственное хозяйство городской среды внушает мысль о сложном жизненном космосе, который даже в общей картографической проекции можно членить, сортировать, интерпретировать. Не таков крестьянский дискурс - его материя говорит о его элементарности, скудельности, бедной чистоте. Опорный же концепт дискурса городского попросту неразличим, настолько многослойна его структура. 
Таким образом, крестьянский дискурс - это речевая вариация малоподвижного деревенского пейзажа. Это бегущая строка повседневных очевидностей; это разговорная машина, производящая круговую панораму однотипных целей, комментирующая набор стандартных производственных акций и формулирующая неширокий круг из года в год воспроизводящихся намерений. Крестьянский дискурс - это незамысловатая стенограмма бытия, направленного прежде всего на обеспечение минимума условий для продления рутинных хозяйственно-экономических практик. Кратчайшая формула такого порядка - «сыты, обуты и одеты». Это и есть принципиальная схема типичных крестьянских дискурсивных практик, их сердцевина, их нищета и рутина. Но эта унылая циклическая норма вмиг освежается, становится отчетливой, когда на нее смотришь из другого дискурса. Этот эффект схвачен А.С. Пушкиным: романтический поэт Ленский, выучившись в Европе, приехав в сельское поместье, войдя в соседские отношения, окунувшись разок-другой в тамошний дискурсивный поток (по сути, мало отличающийся от крестьянского), буквально отшатывается: «Бежал он их беседы шумной. / Их разговор благоразумный / О сенокосе, о вине, / О псарне, о своей родне, / Конечно, не блистал ни чувством, / Ни поэтическим огнем, / Ни остротою, ни умом...» ${ }^{4}$. То есть всем тем, что характерно для салонного дискурса, где надлежит быть красноречивым, умным, проницательным: ум сверкает в тех дискурсивных ситуациях, когда «скрытая сущность вселенной» публично извлекается на белый свет, когда ты - «парадоксов друг»; когда высказывается то, что меняет экзистенциальные координаты. Но координаты крестьянских миров выстроены, что называется, раз и навсегда, они безоценочно приняты и не нуждаются в «перетакивании».

Дискурсивные «нерассуждения», записанные в разных уголках сельской России, - это инстинктивный способ самосохранения, выстраивания социальноисторической безопасности. Не рассуждать и не оценивать - значит не разрушить, не покалечить и даже как-то оправдать, принять пройденное пространство жизни - «жизнь прожить - не поле перейти». Крестьянский дискурс - не описание возможностей, которые были даны, но не реализовались (такое описание аналитично, оно есть «рассуждение»), а, скорее, движущаяся топография пережитого и прожитого, т.е. никаких «ежели да кабы»! Никакой детерминации будущим, и только так - «бог даст день, бог даст и пищу»; «поживем-увидим»: только детерминация настоящим и прошлым - опытом отцов. В этих свойствах крестьянских дискурсов прочитывается основательность, захват мира в его необходимой полноте.

Приведем пример. В апреле 2016 г. в манеже Дворца спорта в Саратове проходил форум «Единой России» на тему «Современное российское село». Выступая, генеральный директор ООО «Ягоднополянское» Василий Марискин заявил, что не намерен соблюдать принятые в подобных собраниях нормы речи. Присутствующие тотчас настороженно притихли. Вот что он сказал: «Я не буду читать, а от себя скажу простым крестьянским языком. Наше хозяйство многоотраслевое, 3,5 тысячи голов коров, 12 тысяч гектаров пашни в обработке. Мы ни одному банку не должны. Я хочу озвучить крик души крестьян России: $<\ldots>$ молоко не должно стоить дешевле воды. Это стратегический продукт, а мы его продаем за копейки. Обидно, что животноводы в дождь, метель, туман и мороз идут на работу, но получают мизер, так как их продукция ничего не стоит. Это надо правительству

4 Пушкин А.С. (1981) Собрание сочинений в 10 томах. Т. 4. «Евгений Онегин». М.: Правда. С. 41. 
и Минсельхозу России на контроль взять. Село - опорный рычаг государства. Если нет животноводства, то нет села. Нельзя так работать, когда “один с ложкой, а семеро с сошкой”» [В Саратове фермеры поговорили с Медведевым 2016].

На наших глазах происходит нечто вроде анатомирования языковых покровов официально-делового стиля: он, вроде, есть, но его и нет. От него остались лишь слабые сигналы, говорящие о том, что оратор - человек не совсем уж «от сохи». Он имеет опыт присутствия в президиумах и выступлений с высоких трибун. В тексте доклада то и дело выглядывают лексические манекены - «многоотраслевое», «стратегический продукт», «продукция», «взять на контроль». Однако оратор намерен сознательно уйти от такой социально-значимой манеры речи. Крестьянский язык - это подчеркнуто не официальная, не деловая лексика, это бойкий, разговорный синтаксис, и, главное, - оснащенность пословичными конструкциями, символизирующими народную мудрость. Деревенский хозяйственник, выступающий на важном форуме, попытался, сам того не сознавая, нащупать разницу между, с одной стороны, монотонным и постным чиновничьим бормотанием, а с другой, самодельным, неусловленным «криком души». И этот заряженный эмоцией возглас гораздо вернее, чем развитая, оснащенная цифрами и графиками аналитика, указывает на суть дела, на подлинные вещи мира. Язык не скрыт здесь дискурсивно бесцветной, бесстрастной лингвистической шпаклевкой, он не маскирует и не приглаживает события мира сетями логических объяснений и привходящими недомолвками, он звучит прямо и просто - по-крестьянски.

\section{Голос ушедшего поколения}

Записанные от крестьян рассказы - основной результат Первой крестьяноведческой экспедиции Теодора Шанина (1990-1994 гг.), и объединяет их биографичность дискурсов. Деревенские старики рассказывают о жизни, которая осталась позади, и эта жизнь оказывается суммой жизненных технологий, перечнем способов повседневного существования. Излагаются эти способы и технологии в их буквально тактильных, рельефных подробностях. Почему крестьянские дискурсы, записанные в начале 1990-х гг., выглядят именно так? Помнится, сельчане, разговаривая с нами, ощутили небывалый и невиданный прежде интерес к мельчайшим деталям их жизненной рутины. Никто прежде не приезжал к ним надолго, не приходил в их избы, не фиксировал каждое произнесенное ими слово. Крестьяне с охотой заговорили о своих трудах и днях, порой сбивчиво, нескладно, увязая в подробностях. Заговорили, потому что возникла возможность такого разговора, и появился собеседник, которому крестьянская жизнь заведомо неизвестна и интересна. Так образовались обширные текстовые массивы, которые я рассматриваю как дискурсы. Возможен ли такой ракурс?

В инаугурационной лекции в Коллеж де Франс Мишель Фуко, формулируя правила рассмотрения и анализа дискурса, советовал «<..> идти не от дискурса к его внутреннему и скрытому ядру, к некой сердцевине мысли или значения, якобы в нем проявляющихся, но, беря за исходную точку сам дискурс, его появление и его регулярность, идти к внешним условиям его возможности» [Фуко 1996, с. 79]. Именно так - откровенные, но и осторожные крестьянские 
дискурсы начала 1990-х гг. стали возможны как моменты инвентаризации прожитого и сделанного. Нам удалось установить эту историческую точку и зафиксировать «голоса снизу», подытоживающие пройденный путь. Оглядываясь, респонденты рассказывают социологу свое прошлое, одновременно диктуя этому прошлому; они проговаривают и приговаривают его. Но этот приговор - не столько оценка прожитого, сколько его перекомбинация. Это - извлечение на свет одного и простодушно-стеснительное сокрытие другого. В этом и заключается та незамысловатая режиссура, которая проделывается крестьянскими собеседниками. Именно так - безоценочно, без обычного стариковского ворчания - они вспоминают и «перевеивают» свой жизненный путь, как зерно на крестьянском гумне. В упомянутой лекции М. Фуко подчеркивал, что любой «<..> дискурс следует понимать как насилие, которое мы совершаем над вещами, во всяком случае - как некую практику, которую мы им навязываем» [Фуко 1996, с. 78]. Что же именно навязывают «вещам» (собственной биографии, событиям, отношениям) наши респонденты? Как они подминают под себя эти «вещи», какого рода насилие они совершают над ними? Что в этих дискурсивных деяниях является общим, инвариантным и что в них - своеобразно, уникально, неповторимо? Далее мы приведем избранные фрагменты одной крестьянской повести с авторским комментарием. Вслушиваясь в «голос снизу», я попытался проделать опыт его дискурсивного чтения, нащупать и объяснительно воссоздать органику крестьянской дискурсивности.

\section{Дискурс крестьянской повседневности}

Словесный портрет респондента Ивана Васильевича Цаплина (1914-1994 г2.), «дяди Вани Белого», так его зовут за чистую, яркую седину.

Его знают все, и не только в Красной Речке, где он живет, но и за ее пределами, в окрестных деревнях в радиусе 30-40 км. Это не случайно: Иван Васильевич долгие годы проработал мельником на единственной мельнице, которая осталась в Красной Речке. И даже сегодня, когда он стар и плохо видит, он помогает односельчанам и приезжим размолоть зерно на дробленку для домашней скотины. Иван Васильевич - крепкий старик с громадными узловатыми руками, ходит вразвалку, неуклюже, крепко опираясь на землю. Наблюдателен, следит за реакциями интервьюера, меняет темп и строй разговора, когда чувствует, что от него добиваются чего-то иного, чем он сам хочет сказать, порой игнорирует или отмахивается от вопросов. Когда на него «нажимаешь», притворно гневается, но чуть погодя отвечает.

\section{Транскрипт ${ }^{5}$}

«Деда моего звали Павел Алексеевич, умер он в 1930 году. Мне было в то время шестнадцать лет. Дед мой - все время старостой был! Пил вино, вот

\footnotetext{
5 Запись была сделана в 1992 г.
} 
я в него уродился. А вот когда ему было пятьдесят лет, он работать бросил. И отец мой стал руководить всем этим нашим хозяйством, собственным. Василий Павлович, отец мой, работал вот кем - хозяином на своей земле! Тогда земля была-то... Сейчас, вот, болтают, земля-то чтоб была продажная. А хрен ли толку, ежели ее продадут?! Подохнет весь народ к ... матери. А тогда была, у каждого, лошадь в руках, да еще и не одна. Плуг был, и борона была. А сейчас?! Щепкой, что ли, землю ковырять?! Ну? Чем? Ну, вот, я землю возьму. Ну, посажу руками помидоры, огурцы, капусту. А пшеницу где ты будешь брать?! Чем ты будешь землю обрабатывать, москвичка хренова?! Ну, по правде?! Огурцы-то ведь - это огурцы. Овощ! Скотская еда. Ну, вот мы ее сейчас раздербаним, землю-то. Что получится?! А тогда была земля на душу населения, душевая. И вот, у меня если нет лошади, - то я ее стремился нанять. Вот, у тебя, скажем, три лошади. Я у тебя лошадь нанимаю и обрабатываю свою землю. А у кого, скажем, нет силы нанять, те землю из половины сдавали. Половина - твоя, половина - моя. И все равно ты будешь с хлебом, если ты даже слабый, если у тебя не на что лошадь нанять. Но все равно раньше было хуже! Колхоз, по-моему, лучше, чем единоличник. Вот, слушай-ка! Колхоз это вещь! Вот мы его тащим, растаскиваем аж с тридцатого года. Шестьдесят два года тащим! И ни хрена не растащим! Понял?! Вот, когда мы вступили в колхоз, у нас одна была корова, Субботка. А сейчас и счету нет, сколько их там. А режут их ежедневно, и все никак не порежут! Колхоз этот самый режет их, едят, гуляют, пьют! Э-эх! Да и хрен с ними! И тебе достанется».

Это пример дискурса приятия и синтеза, общего захвата ситуации, понимания и примирения с ней. Иван Васильевич Цаплин демонстрирует базовые характеристики крестьянского дискурса: мир в нем забирается целиком, в его завершенном облике. Дискурс обобщающей демонстрации, а не раскапывающей аналитики предстает здесь в его широком феноменологическом развороте. Угадывается здесь и дискурс «трезвой насмешливости» над перевернутым миром и в то же время лукавой приспособляемости к нему.

«Ну, давай еще про деда говорить. Он старостой работал. А когда он поработал, когда кончил, в 1920 году, он летом уезжал в Петровск. Петровск это 30 километров отсюда. Как только яблоки начинает давать сад, он в Петровске и торгует там яблоками. У нас сад-то был - гектаров десять. Бабушка - она все время хлебы пекла, в колхоз, в тридцатых годах. Она позже дедушки умерла, году в тридцать седьмом. Она все время хлебы пекла в колхоз. Она пекла здорово! А дедушка мой был озорник. Если у ней хлебы не выйдут - бывает, что перекиснут, у них корки отстают - дед собирает деревянные ложки, подымает корку и все ложки туды потолкает. В хлеб, под корку! А ругаться он матом - не ругался. Он говорил: “Тур твоей матери!”, только так. Говорит: “давай, тур твоей матери, обедать!”. Бабушка - хвать, а ложек нет. А дедушка говорит: “Ты куда дела ложки? А ну, давай хлеб!”. Она даст, а он скажет: “Ну вот, - с ложками хлеб испекла". А она знала, что это он, но не говорила. Она хитрая тоже была, бабушка».

«Старшая была у отца сестра - Мария, а вот с какого года, это я не скажу, она самая старшая была. Ее забрали по линии НКВД, в тридцатом году, и увезли. Вот в этом вот доме их собирали, таких вот. А у нее было семь детей. Их раскулачили, тетку Марию. У них был свой магазин! А что это? Это был 
хлев, а не магазин. Каменный хлевушок, вроде эдакой мазанки. Муж у ней торговал, ездил. Поедет куда-нибудь - в Саратов, в Рязань, еще куда, привезет воблы сухой, конфет. У них было семеро детей. А он привезет товару, торговать, а потом-то сам уезжает опять на добычу. А тут у него все растощут на хрен! Ребятишки-то его, растощут. Вот так. И ее забрали, и мужа забрали. Всю семью увезли, и детей вот эдаких, маленьких. Я сам это видел. Видел! Я зря не говорю! Спроси хоть у кого в деревне. У нас один был председатель, дурак, - председатель совета, он и расписываться-то толком не мог. А только говорит: “Сапрать яво!”. Он какой-то картавый был. Покажет на любого бедного ли, богатого ли - и говорит: “Сапрать яво!”. Звали его Петька Герасин. Вон, напротив магазина жил. Дурак какой-то он был! А у меня не одна Мария Павловна раскулаченная. В Яруге жила еще тетка, и ее раскулачили. Тетка по отцу, звали ее Анна Павловна. По улишному ее фамилия была - Узенева. Она моложе была отца, она была, вроде, с девятисотого года. Ее раскулачили и увезли на Колыму в 1930 году. И там она, видать, умерла. Она жила в Яруге, семь километров отсюда. А мужа у нее расстреляли еще раньше. Как получилось? Во время молотьбы. Раньше цепами молотили и лошадями молотили, катками. И вот были сложены стога такие, крест-накрест - одонья. Ну, он залез наверх. А в те поры был самый переворот. И ему надо бы красный флаг выкинуть, а он взял и белый флаг поставил на одонья. Его забрали и расстреляли, как контру. Это в революцию было. А жену его вместе с детьми в корчевку угнали».

Рассказывая о родне, Иван Васильевич дискурсивно обходит (не минует и не уклоняется, а поштучно перебирает) памятные ему жизненные сцепления. Причем драматизм обстоятельств сам собой переплетается здесь с житейским балагурством, с покровительственно-добродушным зубоскальством. Эта сцепленность, вероятно, один из существенных индикаторов крестьянских дискурсивных практик, присущих именно дедовскому поколению. Мало того, нечто летописное, эпическое («добру и злу внимая равнодушно») можно расслышать в этом размеренном рассказе, оснащенном живописными и разнокалиберными подробностями.

«Знаешь, как говорят? “Хорошо тебе живется, да вот плохо отдается!”. Понял? Дедушка-то наш жил! А семья-то как жила? Дети его как жили? Знаешь?! Ну вот, семья-то хреново жила. Отец вкалывал крюком. Не травокосилкой он косил, не комбайном, а крюком! А ведь это знаешь, как крюком косить?! Сороковую десятину! А он здоровый был, отец-то у меня. Он худощавый был, высокий. Он косил так: крюк берет и пошел. За ним три женщины шли, чтоб вязать. И еще один с граблями шел - подбирать, согребать. Работали так, чтобы колосок нигде не валялся! Увидит если отец, что колосок остался, он пойдет и тебя ка-ак трахнет! Как обругает! А пшеницу-то, знаешь, как теребили? Пшеница она не так высокая, так ее руками теребили, чтоб ни один колосок не потерять. Не жали ее, а теребили, дергали. Прямо из земли. Руками теребили! Чтоб не потерять. А просо?! Как щипали его, знаешь? Вот, выводят всех на поле. Щипать просо, полоть. Приговаривают: “Просо - с ложку, каша в плошке”. Это значит: просо выросло если высотой с ложку, то и каша уже у тебя будет в тарелке! Говорят: “Полите, полите, полите. Теребите травку!”. Вот и ходят, приговаривают, нудят незаметно. А ты сидишь в борозде на карачках. Зато уж и проса были чистые, хорошие!». 
«В Гремячке только один дом сейчас под соломой, у Нюрки. Вот как с моста сойдешь, он по правую руку. Тебе про нее рассказать? А он у тебя записывает? (кивает на диктофон - B.B.) Ну, ладно. Вот к ней один, к Нюрке-то, приспособился. Военный. А она, эта самая Нюрка, она рябая. У ней вот тут будто бы горох молотили. Да ты, чай, знаешь! Ты не видал ее близко? Ну, ладно. Ну вот, приспособился он к ней, она его приняла, военного-то. Он с ней ночь поиграл, он думал, что она молоденькая. А утром встает и спрашивает у Нюрки-то, у рябой: “Бабушка, а бабушка, а где Аня?”. А она, Нюрка-то, и говорит: “А это сама я”. Он на нее поглядел и бежать оттоль! Он ночью, что ли, к ней приехал. Ночью, конечно. Или кто-то его, наверное, к ней нарочно подсунул - переночевать. Ну, он и выпимши, видимо, был».

«Знаешь, я тебе расскажу, про Россию, про Советский Союз. Это было, знаешь, в каком году? Я, вот, родился в 1914-м. А в 1917 году была власть такая - красные были и белые были. Я-то это не помню, это мне дядя рассказывал. "Вот, - говорит, - иду по городу. Ага. Стоят. С этими, с дубинками. Наблюдатели-то. Спрашивают его: “Ты за каких?”. “Я за красных”. А он, который стоял, - белый! Говорит: “Ну-ка, скидай штаны!”. Он скидат штаны, и ему всю жопу напороли. Пустили его, побежал. Дальше бежит, там другой стоит. Спрашивает дядю: “Ты за каких?”. “Я за белых”. А он, этот, который спросил-то, - он красный. Опять его пороть, тур твою мать! Это было! Было! Ну, он опять бежит дальше. Опять кто-то стоит. Спрашивает его: “Ты за каких?”. А он: “Ни за каких, ни за каких! Нате вот! Нате вот!”. Скидат штаны: “Нате, нате - бейте! Только пустите!”. Не поверишь ты мне?! Нет? Это мне дядя рассказывал. "Нате, - говорит, - бейте меня, порите жопу, я ни за каких”. Это было! “Куды, - говорит, - не ткнусь - везде порют!”».

Обратим внимание, что во втором эпизоде Иван Васильевич Цаплин трижды по ходу этого, очевидно, выдуманного (либо приукрашенного) повествования решительно настаивает на подлинности этой истории. Здесь, как мне представляется, в полную силу разворачивается дискурс бытийного режиссирования, присущий той фольклорной атмосфере, которая явственно ощущалась в деревенском социуме времен Первой шанинской экспедиции. Обволакивающий дух вымысла смягчает и наивно обустраивает картинку бытия. Крестьянское «нерассуждение», беззаботное пренебрежение взвешивающей логикой и любыми рациональными резонами конвертируются в сказочное происшествие с классическим троекратным повтором и благополучным исходом. Та же история с чужаком-военным, который смущенно сбегает из теплого деревенского приюта. И это обминающее распрямление мира - характерная черта дискурсивных манер поколения дедов. По мере исторического движения именно такая дискурсивная манера будет блекнуть и постепенно совсем исчезнет. И ей на смену явится дискурс скабрезной байки, пошлого анекдота, «прикольного» происшествия. Развернется и начнет свою работу дискурс городского цинизма, скепсиса и недоверчивой разрозненности людей.

«Видишь, гвоздь в потолок забит? Кованый, лошадиный. Свету-то раньше не было! Лампа керосиновая на том гвозде висела. Вот, мы раньше гуляли, знаешь, как? Это, вот, хорошо, когда лампа есть. А вот нет если лампы? Берешь блюдечко. В блюдечко нальют масло. И ваточку эдак сделают и зажигают. А масла нальют постного. Зажгут - оно и дымит. А гостей в дому - три или четыре стола, тур твоей матери! И одно вот это блюдечко! Вот что было хо- 
рошо - голышом придешь, никто не видит (смеется). Ни галстука, ни хрена! Вот что было хорошо! Полати были прямо под потолком. Ну, уж не совсем под потолком-то! Надо, чай, чтоб ты там спал, ворочался. Вот сперва залазишь на печку, а уж с печки туды. Вот говорят: “Куды поехал?”. “Да с печи на полати”. Да, это действительно с печки лазили на полати. А тут вот, впереди норка такая, оттоль глядишь вниз. А нас было шестнадцать человек в семье, в избе. И вот оттоле и глядишь. А тут человек восемь-десять сидят за столом, больших, рабочих. Рассядется здесь рабочая сила-то. А вот эдакие вот, маленькие, там на полатях. Глядим оттуда: чаво, мол, они едят?! Ну, куды деваться-то?! Тут все рабочие сидят. А мы, ребятишки, залезем туды, на полати, оттоль и поглядываем. А спали как? Знаешь? Вот тут вот ягнят натаскают - полну избу, штук 15-16 натаскают. Корытечко овса поставят, насыпят, воды нальют. Ночуют ягнята в избе, от холоду. Теперь согребают всю солому и ее вон в эту избу, туды. Там эту солому по всей избе разваливают, расстилают, какой-нибудь полог найдут: и кто где сумел лечь, там и спи. На полу! У каждого койки-то не было! Спали на печке, на полатях и на полу! Ну, шестнадцать человек было, как ты думаешь! Понял?! И везде, где уснешь, там и хорошо! Как набегаешься или наработаешься. Вот эта печка вот, а с печки - на полати мы прыгали. На печке полно народу, и полати полны. И там, в избе, тоже полно. А туды еще, в избу-то, зайдешь или не зайдешь: там ведь большие спали. Вот и жили».

Воссоздаваемая стариком Цаплиным картина мало кого может удивить. Она неплохо известна по отечественной художественной литературе - от Бунина до советских писателей-деревенщиков. Однако в рассказе «дяди Вани», как я его называл в наших долгих разговорах, явственно слышится дискурс сожаления о минувших порядках семейного, тесно сплоченного, сбитого в нерастаскиваемую цельность бытия. Думается, что это естественная социально-психологическая реакция на нынешнюю заброшенность старика, который вынужден после недавней смерти жены жить один и самостоятельно себя обслуживать. Его дочь Мария, живущая с мужем Михаилом и сыном Кириллом невдалеке, время от времени проведывает отца, забирая в стирку белье и принося еду, - обычно битую говядину, квашеную капусту и погребные соленья. Хлеб и самогон дядя Ваня изготавливает самостоятельно.

«Все у нас тут на воровстве поставлено! Вот, я после фронта на тракторе поработал, а брат мой двоюродный был бригадиром. Он мне и говорит: “Иван, бросай трактор!”. И берет меня себе в помощники по технике. Ну, я стал работать там. А хрен ли, все разъедутся, а я любую траву кошу и везу домой. И хлеба много в запас: комбайны-то идут мимо. Из бункера прямо хлеб брал. А комбайны тогда тракторами таскали. Иван Иваныч наклал пять мешков, там, на меже. А я накосил этой вот травки. Как следоват накосил! Ну, ехать надо домой. Жена приехала ко мне, на корове. Поклали мешки в телегу, сверьху поклали сено. Пять мешков и сено. Люди чтоб видели, сено-то, по обликуто. Но у меня-то под сеном - два с половиной центнера зерна. А то и три! А это дело было там, где Красный ключ. Там же овражек есть, низок! И вот, вся душа у меня выболела - вот не вывезет, вот не вывезет. Доехали до горы, дал ей отдохнуть, спустился вниз, еще дал ей отдохнуть. А сзади меня подвод, наверное, десять, да впереди, может быть, столько же. И все сено везут. 
Народ глядит! А мне ехать надо, я ведь пробку делаю! Ну, я корове говорю: “Ну-ка, пошел”. Ее Телкой звали! Всех тогда так звали. Говорю: “Ну, Тела". Все-таки выехали в гору! А бабушка моя молиться богу начала. Не подвела Тела нас».

«Ты не был в Березовке? Там, где у нас вода начинается? Там у нас гумно было. Вот когда я пришел оттуда, с фронту-то, взял мешок. А попал мне мешок брезентовый. А в него входит шесть пудов, это почти сто кило. Теперь я пришел туды, на гумно, насыпал его. А не пшеница была, рожь. Ну, насыпал его, взял, положил на плечо и пошел. Понял? А идти мне пять километров или даже больше. До самого отряда. На себе тащу его, думаю: “Эх, тур твою мать, чаво же это я делаю-то?!”. У меня уж в глазах темно делается. Думаю, сейчас сыму мешок с плеч, а обратно-то уж ни за что не подыму. Вот, может, через это и ослеп. И я его тащил до самого отряда. Нет, вру! Иду я, гляжу, стоит тумба. Ну, столб. Я приладился, мешок этот на столб поставил. Он, столбик-то, не высокий такой, тупенький. Отдохнул маленько, опять на плечо положил и пошел. А отряд-то у нас был на желтой горе, где ты фильм-то снимал с режиссером. Вот это место. Ну, я до него маленько не донес, схоронил. А у меня в отряде стояла лошадь с телегой. Я ее выпряг, она паслась. Ну, я в отряд пришел, лошадь запряг, приехал, в телегу мешок положил украдкой, чтоб люди, трактористы-то, не видели. Закрыл его и уехал домой. Вот какое было терпение, тур твою мать! А мешок был брезентовый, такой коришневый, вот эдакой ширины. Шесть пудов в него входит. Рожь я эдак на себе тащил». «У меня все время корова была, перерыву не было. Как вот, до войны купил Телу, так до нонешнего дня держу коров. Всю жизнь с коровой. Как женился, в девятьсот тридцать пятом году, ни одного дня без коровы не живу. А свиней я много не держал - одну, две. Зато сала - вот эдакий вот слой! А это зависит от условий, а не только от корма. Пол в свинарнике должен быть хороший и кормить надо вовремя. Я один раз поехал в Петровск, в мае месяце, и купил там поросенка. А уж к ноябрю в нем было пять пудов. Знаешь, какой это был поросенок?! Вот тут речка текла - она была ближе сюда, чем нынче. Это она сейчас прочь от мельницы ушла. А тут раньше был каус, речка - все тут было! Ну вот, он, поросенок-то, выйдет из хлева, спустится к речке, там находится, набродится, накупается. Потом по берегу походит, зеленой травы наестся. Как человек был! Даже в огород не лазил. Вот он травы похрупал, поел, накупался и идет домой, в хлев. Во-от был какой, тур его мать совсем! А вот это вот сейчас, - сволочь! Я, вот, борова взял в Оркино, а дети взяли свинку в Гремячке. Ну, они вместе жили, и свинья обошлась. А они ее было резать! А я говорю: “Да она же супоросая! Чего вы будете ее резать?!”. Они мне: “Да, тятя, где?!”. Я им: “Да погляди-ка, у нее вымя уж, тур вашу мать!”. Ну, я им не дал резать. И она пятнадцатого марта опоросилась. Они мне в избу поросят принесли. А они мне, поросята-то, ночью спокоя не дают. Дети мне принесут молока, и я их ночью сижу, кормлю. Выкормил! А их шесть. Ну, осень пришла, я говорю: “Дайте мне хоть одного-то. Я не ухаживал, что ли?!”. Ну, обещали. А видать, хрен дадут они! Мне-то и не надо, а вот детям! У меня же еще есть дети в Саратове. Я этим говорю: “Что вы, мол, у меня детей городских отбить хотите?! Они ко мне приедут, а у меня нет ничаво им дать!”. Правильно, нет? Когда у меня было все, я им всегда давал. Сколько они отсюда сала возили! 
Один раз свинью зарезал, килограммов на восемьдесят и поехал через Бурасы в Саратов. Отъехал отсюда до Бурасского крыльца, где сельпо, положил свинью рядом. Сижу, жду автобус. Ну, подошел автобус, а я свинью в него никак не подыму. Мне помогли потом, и ее туды, прямо к шоферу, перевалили. И я еще шоферу сказал: “Ты мне, мил-человек, на Второй Дачной останови”. А он, видать, забыл и меня увез на вокзал. Я стал ругаться: “Зачем ты, мол, меня увез на вокзал?! Что я буду делать с ней, с тушей-то этой? Я же с ней ничего один не сделаю!”. Он говорит: “Ну, ладно”. Пошел, какого-то шофера нашел, на легкой машине. Меня спрашивает: “Будешь платить три рубля?”. Это меня тот шофер спрашивает, коий на автобусе меня привез. Говорит: “Я, мол, пересажу тебя на легкую машину, и он тебя до места довезет”. Я говорю ему: “Заплачу три рубля!”. А тот уж меня выгоняет из автобуса-то. Я говорю: “Не пойду! Куды ты меня выгоняешь, чаво я с ним буду делать?! Его ведь не подымешь!”. Ну, подошел тут шофер с легкой машины - молодой такой, хороший. Они, два шофера, забрали этого борова и в машину положили, в легкую-то. Поклали, поехали на Вторую Дачную. А я трезвый был, я ни хрена не пьяный был! Да. Подъезжаем, даю сигнал, на третий этаж. Выбегает внук. Ну, я перекрестился. Добрался, слава богу! И ведь борова привез! Целиком! А уж сейчас я не осилю, нет! Вот, вчера сплю тут, а сна-то у меня нет. От тяти-то уж помощи им мало, детям-то. Как ты думаешь, хорошо это?».

Этот фрагмент - классический пример дискурса крестьянской обстоятельности и непрерывного внимания к подробностям повседневного существования. Я много раз ездил в изучаемую деревню и обратно в Саратов тем же маршрутом, что и Иван Васильевич. И хорошо знаю эти колесные практики. Все точно! Но вот эта полная погруженность рассказчика во вспомогательные, неосновные жизненные акции, его круговая внимательность к мельчайшим деталям, его растерянность перед непредсказуемостью городских отношений и упорная воля к их развязыванию, а также готовность смириться с возможным провалом - это перебирающее дискурсивное поведение очень содержательно. Оно указывает на внутренний двигатель этих почти непосильных действий. Забота о потомстве, причем забота в ее именно натуральном (не денежном) варианте, выразительно вскрывает базовое настроение крестьянского мира - быть кормящей и обеспечивающей системой. И за кулисами спектакля под названием «Доставка» - детализированная событийная череда, забавно открывающаяся купающимся в речке поросенком. Дискурсивная освоенность этого ветвящегося мира подробна, пооперационна, нацелена на счастливый конец и в то же время постоянно готова к фатальной неудаче - «кому - как, а нам эдак».

«А коллективизацию организовал район. Только что район! Организовал всю эту хреноту район, колхозы-то. У нас уполномоченный был, Манушкин. И его убили к гребаной матери. В Гремячке, на мельнице. Ведь не шли в колхоз многие! Их насилкой загоняли. Не идешь в колхоз, тебя по линии НКВД хватали и угоняли. Одного, второго угонят, пожалуй, и пойдешь! Того забрали, этого забрали. Думаешь: “Эх, я лучше зайду в колхоз, а то и меня, мотри, тоже заберут”. А ты знаешь, неохота было свою-то землю отдавать. Насилкой загоняли! Насилкой в колхоз гнали! Ну, как же я не помню?! Мне уж было шестнадцать лет. Я провожал кулаков, сам. "По этапу” это называлось. Провожали их от сельсовета до сельсовета, под расписку. Я, вот, с одним пошел, а мне 
было шестнадцать лет. А я как исполнитель был по сельсовету. Вот, его раскулачили, а он был лет на пять старше меня. Ну, еще молодой он был парень. Ну, наш он был, краснореченский. Друг дружку мы знали, и мне его вручили. Сказали: “Ванюшка, отведи его в Сокур!”. Ну, тур его мать, я парнишка ведь, мне шестнадцать лет. Что я с ним буду делать?! Дали мне с собой ружьишко с патронами. А идти-то надо большой дорогой. А он поумнее меня-то был и говорит: “Давай, Иван, пойдем напрямую. Через Елоховку. Вот, низом”. По толам он повел меня. И уж не я его, а он меня повел. Вышли за деревню, идем. Дошли до середины Елоховки (урочище, где густо растут ивы и ветлы; тянется по речке километра два-три - В.В.). Он говорит: “Иван, давай пообедаем". Я говорю: “Ну, давай. Садися, обедай”. Он обедает, а я отошел маленько, а сам гляжу на него. Он расстелил шубенку, помидоры у него были, арбуз у него был. Ну, поел он и говорит: “Иван”. Я говорю: “Чаво?”. Он говорит: “Иван, ты здесь покарауль, а я пойду, оправлюсь”. Я говорю: “Ну, ступай”. А чаво же я ему буду в ширинку глядеть, что ль? Ему бы сразу мне сказать, что я сейчас, мол, уйду. Ну, убегу. А то он отошел немного и ка-ак рванет! Аж толы захрустели, как лось бросился от меня. Я кричу: “Илюша, Илюша!”. Его Илюшей звали. “Илюша, Илюша!”. Нет, Илюша мой не откликается, убежал совсем Илюша. Ну, я тогда стрельнул. Никто не откликается. Ну, я иду домой. Думаю, сейчас меня посадят! Как я буду отчитываться-то?! Иду, тур твою мать, стоит столб. Я заинтересовался, - как, вот, наш Кирюшка. Я снял ружье, прикладываюсь, и в столб из ружьишка ударил. Подошел к столбу, поглядел, полюбовался и пошел ни шатко, ни валко, домой, с ружьем. Вот, отправил кулака, тур твою мать (смеется)! Ну что ж, мне в сельсовет надобно идти. А там, в сельсовете, отец мой тоже был, ага. Прихожу, меня спрашивают: “Ну, что?”. Я говорю, так, мол, и так, убег от меня Илюшка. Мне: “Как это так убег?!”. И меня сажают в каталажку, в сени. Велят: “Давай, рассказывай, как, чего! Куды он убежал?”. Я говорю: “Как, как? Вот так и убег!”. “Ну, как он у тебя убег?”. Я говорю: “Зашли в Елоховку, он бросился и убег”. Меня спрашивают: “У тебя же ружье, ты что не стрелял?”. “Да я стрелял! Но у меня-то ружья сроду в руках не было! Я бы не попал”. Меня спрашивают: “Ну-ка, а где патроны?”. А у меня две патроны уж стреляных! Ну, они поглядели на патроны и меня отпустили».

«Когда коллективизацию проводили, приезжал сюда один уполномоченный, но его убили на хрен. Манушкин фамилия. Я видел его сам. Он к нам приехал в апреле месяце тридцатого года. Вот, слушай. Гонят наших в колхоз, а наши в колхоз не идут. Он приехал, а бабы на него как набросились! Он бежать. Вот так вот, через гору. Вот как сейчас я это вижу! Он верхом, а бабы за нём, за Манушкиным этим самым. Бабы за нём, и гнали его, и гнали. Наши краснореченские бабы. Восстание произошло! А у нас вот, - Яшунькина Андрея сын. А это - брат его. Он постарше меня на два года. Он залез на колокольню и взялси сигналить. Восстание! Ну, загнали его, Манушкина-то, в мельницу, в гремяченскую, и убили. Потом приехал другой. Этого я не знаю, как его зовут. Тоже, чтобы организовать колхоз, он приехал. И вот мой дядя, он с девятьсот второго года, и еще дядин брат двоюродный, они его напоили, этого второго. Они его напоили, бутылкой ему трахнули по голове, прям по башке, и в снег его закопали. Думали, что насмерть. А потом поглядели, его нет. Он, наверное, раздыхался и убег! Но никто никуды не пожаловался, и никто 
никому ничего не сказал. Понял! Это дядя Петр сделал. Петр Павлович Цаплин. Лихой был народ! Да, да. Вот ему и дали бутылкой-то. Но тоже, не сообразили: его закопали, а шапку взяли и на крышу закинули. След-то остался! Но он не пришел - ни за шапкой, ни за чем».

«Сначала был крестком - крестьянский комитет, он помогал людям с плугами, боронами, лошадьми. А в тридцатом году или в двадцать девятом у нас, в Красной Речке, был организован колхоз под названием «Пролетарское единство». Лошадей отбирали, потом инвентарь отбирали, отвозили его весь за село, вон туда, где сейчас пруд вырыли. И весь инвентарь расстреляли, из ружьев. Вот, Панька Игошин и Васька Оришин. Взяли ружья и по сохам да по плугам, да по мерам, из которых зерно рассевали, взяли ружья и ударили! Подкинут вверх и расстреляют. Издевались: мол, это все стародедовские приспособления! Чтоб не было их! А чтоб был трактор, чтоб был колхоз. Они ждали общего одеяла! Тогда говорили, что, мол, под одним одеялом все будем спать. Ты слыхал про такой разговор? Общая, мол, будет одеяла, и все будем под ней спать. А, глядь, никто не лег туды. Все под своей одеялой норовят выспаться. Это, вот, было в тридцатом году, а сейчас - девяносто второй доходит. Видишь, шестьдесят два года прошло, а никто ни хрена под такое одеяло не лег!»

Пожалуй, это единственный, более или менее развернутый, складный рассказ Ивана Цаплина о краснореченской коллективизации, о ее ключевых сюжетах, оставшихся в его памяти. Никаких особенных ужасов в строе повествования не просматривается, а ведь именно в это время, в начале 1990-х, в российской публицистике (как печатной, так и телевизионной) можно было наблюдать эшелонированную трагедийность, развернутые в подробностях драмы крестьянских корчевок, в конечном счете искалечивших крестьянские миры России. Эта историческая правда подавалась, как правило, в ее раскаленном, разгневанно-клеймящем облике, и все мы каждодневно наблюдали эти журналистские проклятья сталинскому режиму. Совсем иначе коллективизация выглядит в дискурсе натуральной крестьянской повседневности, и это, надо полагать, вовсе не следствие простительной человеческой забывчивости. Здесь, как мне кажется, неясно просвечивает загадочный феномен социального равнодушия, исторической терпеливости и даже бесчувственности к драматическим поворотам бытия. Это заметил, размышляя о значении творчества М.А. Шолохова, литературовед П.В. Палиевский. Он формулирует догадку о том, что «общая атмосфера жизни и ее давление у М.А. Шолохова принята намного суровее, чем обычно у всех классиков мировой литературы; именно принята, а не с ужасом, отвращением или злорадством отображена». В этом контексте «принятая суровость» идет об руку с некой невозмутимостью, с явным пренебрежением к возможной нервозной впечатлительности конкретного субъекта. Автор видит, что в шолоховском мире происходит «самая свирепая проверка человека на прочность; кроме того, этот мир ни секунды не колеблется перед таким понятием, как личность. Не отвергает ее и, без сомнения, чтит, но, если надо, свободно перешагивает. Сострадание и сочувствие к ней не исчезают; но одновременно идет одергивание, обламывание, обкатывание ее в колоссальных смещениях целого» [Палиевский 1979, с. 274-275]. Такого рода «обламывание» (в его разжиженной, простоватой по сравнению с художественным текстом версии) слышится и в дискурсе Ивана Цаплина. Вслушиваясь в его рассказ, прикидочно вправляя себя в эти зловещие мизансцены, тотчас понимаешь, 
насколько было естественнее и бережливее нечувствительно приспособиться к их давлению, чем ненароком раздразнить властных экзекуторов подручным дубьем или яростным взглядом исподлобья.

«Много! Ох, и много раскулачили! И самых ценных людей, которые только и могли работать. И кормить! Не только что себя, а и государство могли кормить! Да, да. Что ему мешало? У него, у того, который работал, хотел работать, у него была и масленка, и мельница, и дранка, и чесалка. Все свое! Вот я имел землю! Ну, я-то не имел, а отец мой имел. Сеяли подсолнухи. И я помню, я сам гонял масленку. Привод к ней был лошадиный. Она была не как заводская, а как своя, крестьянская, самодельная. У нас рядом стояла масленка. Я пойду лошадей гонять, мне жмых дадут, чтоб я лучше работал: я же мальчишка еще, а он сладкий, этот жмых. Он не колоб, он не до конца выжатый, он еще теплый, мягкий. Ух, тур твою мать, какой он хороший, вкусный! Колоб-то мне на кой? Зубы об него ломать?! Была такая, вроде газового баллона, жаровня. Тут горн, шелуха от семечек горит. И мужик сидит, трясет эту жаровню, чтобы семечки не пригорали, с места на место их пересыпает. А тут колода стоит. Он вываливает из жаровни семечки обжаренные. А тут жом с винтом. Вываливает в колоду семечки, а в колоде полотно. Колода деревянная, а жом металлический. Но колода не из досок! Она цельная, из дерева долбленая. И вот жмут, и масло текет».

«У меня корова была стельная. А дело было как раз в это вот время, на Кузьминки. Ну, бабушка мне говорит, жена моя: “Ваня!”. Я говорю: “Чаво?”. “За коровой-то следить надо!”. Я говорю: “Ну ладно, я сейчас пойду”. Раз сходил, два сходил. Теперь иду, но мне оправится надо было. В конюшню. Ну, сажусь. Сел добром, затворил дверку. Тепло мне, сижу, оправился. А стал выходить - хрена с два! Я запертый! Я торкался-торкался, ни хрена не отпирают. Меня заперли! А когда я все-таки вышел, то сразу понял: жулики были у меня на дворе! А это были Кузьминки, середина ноября. Кур воруют в это время, семь кур у меня забрали, на хрен, и ушли, а меня оставили, заперли. А проволочку-то люминевую воткнули в пробой. Я бился, бился, потом ка-ак плечом дам! Проволочка вот так вот согнулась, и цепь слетела. Прихожу домой, говорю: “Бабушка”. Она: “Чаво? Чаво ты ходишь, не спишь?”. Я ей говорю: “Тур твою мать, меня в конюшне, чай, заперли!”. Это было как раз на Кузьминки. Утром встаем, а у нас кур-то нет! Меня заперли, я им мешал. Я встал, а они попрятались во дворе, жулики-то. А как я зашел в конюшню, они меня и заперли. Кур потом собрали, на хрен, и ушли восвояси. Семь кур утащили! Говорю бабушке - так, мол, и так. А она говорит: “Да бог с ними”. Эх, у меня бабушка хорошая была! Это было не так давно. Мы уж с бабушкой старые были, вот. “Да бог с ними”. Только это она и сказала. Кому надо, не трог - пущай берут».

Перед нами очередной извод дискурса крестьянского терпения и нечувствительного смирения перед обстоятельствами бытия, что был охарактеризован выше. На этот раз в несколько сказочно-балагурской тональности. Помнится, навела Ивана Васильевича на этот рассказ именно ноябрьская пора. Он по старинной привычке мерил течение времени народным календарем, а Кузьминки (14 ноября по н.ст.) как раз были той субботой, когда я пешком пришел к нему за 34 километра в Красную Речку из Лоха, где жил с семьей во время всей Первой шанинский экспедиции. Принес с собой разное гастрономическое довольствие и пару поллитро- 
вок «Кубанской», которую достать в то время было очень трудно. Уже смеркалось, когда я постучал в его избу. Мы хлопотали вокруг стола, жарили селянку, освежали столовую посуду, выкладывали на стол соленья, потом уселись, медленно поужинали и, находясь в благодушном расположении, дядя Ваня начал вспоминать свои обычные трапезы, когда была жива его жена Аграфена. И как-то незаметно свернул в разговоре на историю о краже кур. И в этом необязательном рассказе в очередной раз обозначились базовые черты дискурса крестьянского существования его ровная предсказуемость, его своеобразная, допускающая разного рода выверты и скачки, нечувствительность, его размашистое великодушие и безмятежность. «Отец мой, кроме хлебопашества, ничего не умел! Он, вот, только что работал, работал с землей. Ему некогда было ремеслом заниматься. А деда мой, отцов отец, когда ему пятьдесят лет сравнялось, он работать прекратил. Понял? Старый стал, считалось. Он вот такую вот бороду отпустил, до пупа. Старый! И все хозяйство передал отцу. Отец командовал: пахал, жал, сеял, косил, молотил. Молотили у нас цепами. Эх, вот работали, так работали, тур твою мать! Вот, у нас было три брата - один с девятьсот пятого, другой с девятьсот второго, а третий с восемьсот восемьдесят восьмого. Все они были женатые. И вот, раньше это называлось “посад”: настелят снопов, колос к колосу, а стебли-то врозь, в стороны. И как начнут их молотить, они аж прыгают, эти снопы, припрыгивают. А их жены-то идут и по гузнам снопы хлыщут. Как пойдут, получается хлеще, чем на молотилке! Вымолачивалось зерно очень хорошо. Но надо тоже это уметь было! Это называется “оплавить колосья". Это значит колос отбить, а гузно не трогать. Вот так! Вот тебе этот самый оплав. Отбить колос! А колос отбить - это просто! Но тому, кто это умеет, кто может. Цепов теперь в деревне не осталось, а раньше у нас в восемь цепов хреначили. И ведь надо ладить! Чтоб никто ни раньше, ни позже не ударил. Такая музыка была - хошь пляши! У меня старший брат был, с девятого года, он тоже вникал в это дело, тоже туда лез, молотил. Ну, он подлаживал, а не ладил. А я в это дело не вникал. Я еще тогда бегал, прыгал, игрался».

«Ты, вот, спрашивал вчера: когда я жил хорошо, чтобы всего хватало. Знаешь, это вопрос какой? Пустой! Человек, мотри, сыт не бывает. Вот у меня сейчас все есть, а все-таки чего-то не хватает. Чего-то не хватает! И с ней, с бабушкой, мы так же жили. Я, вот, думаю, мне хватает. А ей, может, не хватает! Но мы особо хорошо никогда не жили. Не роскошествовали, нормально жили. И особо не нуждались никогда. Я так понимаю! Как хочешь, так и живи! И я как хочу, так и живу! Ты спрашиваешь: я завидую или нет богатым? Так, что ли? Да на хрена завидовать-то?! Никогда я не завидовал. Хочешь жить хорошо - работай! Хочешь выпить - подработай! Короче говоря, трудись! Ведь как говорят: под лежачий камень вода не текет. Тех, кто трудится, и кто не трудится, чай, разницу-то издаля видать (смеется)! Человека-то издаля видать тоже. Если он мал-мала живет, у него и скотинка, и куры, и коровка. Он и выглядит-то поиному! А ежели у него нет ни хрена, то это так и видать, что у него ничего нет. Ты, вот, спрашиваешь, как отличить? Вот так и отличить! Его видать, чай! Гляди и отличай! Вот, я защурю сейчас глаза и все село тебе пересчитаю: кто где живет, и кто как живет! У богатого что? Скотина, хороший дом! Какое-то ремесло богатый обязательно имел. Богатый одевался хорошо, отличался от другого даже по виду. А бедняк? У него скотины нет, и ходит он в одной ши- 
рокоспинке. Широкоспинка у него - одна на всех. Я тебе давеча рассказывал про это. И ремесла в руках нет ни хрена! Вот он и ходит, голодает. Нищие у нас были, тур иху мать! Нищие были, милостыньку собирали, ходили. А если у человека земли много, значит, у него и богатства больше».

Здесь перед нами весьма картинно и впечатляюще прошествовал дискурс крестьянского обобщения и простодушной генерализации. Если принять сформулированный выше тезис о «нерассуждающем большинстве», о «малоумности» дискурса крестьянского существования, то в приведенном тексте он проявляется во всей его феноменологической обстоятельности. Иван Васильевич Цаплин не конструирует систему параметров социального расслоения в деревне, он просто видит их. Его заявление о «прищуре» глаз в ходе перебора ключевых кондиций соседских и всех деревенских семейных дворов имеет прямо-таки методологический статус. «Защурить глаза» - значит избавиться от отвлекающих подробностей и каких бы то ни было детальных, милых сердцу либо, наоборот, отвращающих мизансцен в довольно монотонном репертуаре внутридеревенских отношений. Вообще говоря, захваченность, причем не столько рефлексивная, т.е. по своей природе аналитическая, сколько органическая, стелющаяся, привычно реагирующая на однообразное шевеление фактов деревенской повседневности - родовая характеристика крестьянских жизненных практик. Дискурс заученного повторения натурально сложившихся, немногочисленных бытийных звеньев лежит в основе того, что именуется «репутацией». Подобного понятия в крестьянском словаре нет, но оценка любого семейства в проекции «какого оно роду-племени» обязательна и устойчива. Этот вопрос - в сущности, тот самый «прищур», тот подручный интерпретационный инструмент, каким привычно и машинально работает деревенский социум. «Я нисколь, ни одного дня в школе не учился. Я, вот, с шестидесятого года, когда на мельнице стал работать, вот тут я мал-мала научился писать. Нужда заставила: накладные-то надо подписывать. Родители в школу посылали, было. Брат в школу ходил, и я с ним пошел, но меня выгнала учительница, сказала: “Ты молодой еще, пойди, каши поешь маленько”. А я на нее за это изругался: “Сука ты!”. И больше не ходил ни одного дня в школу (смеется). А чаво она мне?! Я пришел в школу, чин-чином, а она меня выгоняет. Я даже плакать начал. Я пошел с братом, с Алексеем, а она мне говорит: “Выдь отсюда! Кашки ступай поешь”. То да се, молодой, мол, еще. А я, было, тыкву ей принес в подарок, а она меня выгнала на хрен. Я и тыкву разбил, и боле не пошел в эту самую школу. Да и ходить не в чем было. Зачем мне учение? Да и без него я все делать могу! Я и тракторист, и мельник, и валяльщик, и печник, и гребещник. И все делаю сам! Тракторному делу обучался в Озерках. Первый-то год нас назад отправили, сказали, что мы объедим всех, а уж на второй год пошел. И там я вместе с Любкой Шишкиной учился. И там еще была одна женщина, Александра, Санька. Тоже была трактористка. Надо говорить “шатун”, а она всегда говорила - “шатуище”. Ее там так и прозвали - Шатуище».

«А валенки валять я, знаешь, как научился? Я научился у своей мачехи. У меня отец, когда мать померла, в тридцать девятом году, на ней женился. Она выпить любила, тур ее мать! Ну, я раз сварил самогонки ведро и отнес ей, чтоб она валенок нам наваляла. А у ней во-от такие титьки были, у мачехи. Она умела валенки валять, большой специалист была по этому делу. А когда отец у меня помер, в сорок восьмом году, она вышла за другого, за 
Василия Петровича. И он выпить любил. Им принесут самогонки, а они не валяют. Напьются и друг на дружку лезут, тур иху мать! Самогонки не напасешься на них! Ну, я поглядел, как она валяла, раз, другой, третий. Потом сам попробовал, слепил кое-как, понес ей. Она поглядела, говорит: “Ну, пойдет! Да ты еще попробуй, получше. Ну, ты не торопись - вот так, вот так, вот так, Ванюшка!". Да, да, показала - так да эдак. И я еще раз заделал и опять к ней пошел. Она поглядела и говорит мне: “Ну, а теперь сваляшь! Валяй, давай”. И я начал валять, а у меня опять сапогами валенки пошли. Ну, пару, две, три связал - и пошло у меня на лад дело! Так, тур твою мать, к ней идут с шерстью, а она ко мне их посылает: “Вот, Ванюшка Цаплин самый валяльшик”. Мне шерсти навалили полон подпол: и из Гремячки везут, и из Бегучей везут - полно (смеется)! И я начал валять. Один раз восемьдесят пар кряду свалял, чтоб на дом денег заработать. Тогда сто рублей за валенки платили, а водка стоила два рубля восемьдесят копеек. Вот, тур твою мать, водки-то я заработал?! За ночь валенки. Стало быть, за ночь больше тридцати бутылок, полтора ящика! И не пил я ни хрена тогда, не как сейчас! Вот так вот».

«Был, вот, у нас в деревне Иван Федорович, по прозвищу Кулага. Вот я раз кадушки делаю, а он приходит и говорит: “Миленький, да где ты научился?”. Я ему отвечаю: “Нужда научила, от нужды научился”. Говорится ведь: “нужда и барыню гребет” (смеется)! Вот, пойду, ветел нарублю, они высыхают у меня, и я за день кадушку сделаю. И ведь начал кадушками торговать, без смеху! Я и бочки делал, и кадушки делал, и лагуны. Пахтанки делал бессчетно! Я посмотрю, как мастера делают, и сам так делаю. Вот, мачеха показала, как валенки валяют. А вот сосед у меня рядом жил, он бондарь был. И вот у меня один раз что-то рука заболела, я на работу не ходил. Думаю, пойду-ка я к нему. А он дома сидит, кадушки делает, тетке моей. А до этого тетка моя пришла к нему и говорит: “Андрей Сергеевич, у меня из кадушки вода ушла”. А он спрашивает: “А что, там только вода была, в кадушке-то?”. Она: “Нет, огурцы тоже были”. Тогда он спрашивает: “Ну, ладно, вода-то ушла, а огурцыто хоть целы? Остались огурцы?” (смеется). Тетка отвечает: “Да огурцы-то целы, только вода ушла”. А он тогда и говорит: “Воду не удоржишь, и дым не удоржишь! Мочить ее надо, бабушка! Мочи - и она будет воду держать”. Я больше делал липовые бочки, дубовые-то я мало делал. Липу - просто! Как ее жамкнешь обручами, она заминает друг дружку и воду ни хрена не пропускает. И для меда делают из липы. Раньше у нас разные мастера были, в деревне. Вот, Иван Федорович, хомуты шил, ходил по селам. Он шворник больно уж хороший был! А то возьмут, и увезут его, сбрую шить - в Озерки, в Яругу, в Петровск. Гармонь у него была, рубашка, шелком расшитая. Он не был богатый. Ни хрена у него ничего не было! У него все богатство, что руки золотые. Это правда, он чудак был, но мастер! Специалист. А то что он чудак, так это его просто просмеяли. Вот дай ему палку - он враз из палки сделает клещи для хомута. Он только что глянет на лошадь и уже знает, какой ей хомут сделать. А сделает, как выльет! Кнопками весь разошьет. Хорошо! Хороший был мастер. И сбрую, и седелки - все сам делал. А ремни он резал из кожи так: берет кожу и вот эдак дергает ее на ноже (показывает.). Ровно выходит! Хоть куды-нибудь в сторону у него ушел, ремень-то. Нет, нет и нет! Ровно, хорошо! Он мне еще хомут шил для коровы, для Телы». 
В этом фрагменте, в его динамичном, минующим специальные детали и хитрости темпе и заметно скупом на подробности строе внятно прослеживается типичный для крестьянских миров дискурс видения и «нерассуждающего» угадывания, когда мир берется в его слитной динамической целостности. Когда мир захватывается, что называется, чохом. А.С. Пушкин замечал: «Ум человеческий, по простонародному выражению, не пророк, а угадчик, он видит общий ход вещей и может выводить из оного глубокие предположения <...>» ${ }^{6}$. Цаплин-угадчик естественным образом влит в местный пейзаж и в нем растворен. Дискурсивно весь он - неотлучное присутствие, цепкое здесь-бытие. Он непринужденно умудрен и незатейливо искусен, живя в своем родовом гнезде. Он летит над рябью фактов, мгновенно впитывая их сигналы и усваивая их предсказуемо преображающуюся конфигурацию; он видит все и все примечает. Глагол «примечать» повышенно частотен именно в дискурсах крестьянской повседневности. В нынешнем городском лексиконе он прочно запрятан в резервные глубины, а в деревне «примечай!» до сих пор слышится в дискурсе отцов. Перемена обычных приставок творит здесь чудеса. И общеязыковое «замечать» как настораживающее, принудительно-информационное мероприятие, свойственное городским (и вообще изощренным) коммуникативным практикам, выворачивается деревенским «примечать» как действием необязательного посылания и ненавязчивого инструктирования. В то же время в этом глаголе слышится явное и властно-хозяйское овладение миром, его дискурсивный и, следовательно, предметный захват. Это как у грибников - «один беру, на другой смотрю, третий примечаю, четвертый мерещится». Примечающие Иван Цаплин и Иван Кулага - персонажи для нынешней деревни редкие, и в последнее время эту роль начинают своеобразно выполнять переезжающие в село горожане, но это особая тема.

«Нету сейчас народа хорошего в деревне, считай, а раньше вот такие были соседи. Вот сейчас, в это время, ночи стали длинные, осенью-то. А я курил раньше. Встаешь утром, бабушка печку затопляет. Тогда каждый день печку топили: блины пекли, молоко квасили. Ну, встаешь, идешь к соседу, - насидишься, наговоришься, накуришься! Потом идешь домой. А сейчас?! Сейчас друг к дружке не ходят. Это какая хрен жизнь! Вот, скажем, поллитра у меня есть, примерно, так я ее норовлю выпить один, украдкой, кабы кто не пришел! Вот, вчерась пошел подстригаться, у меня была бутылка. Пошел к брату двоюродному, подстригся. Ну, и увел его сюды - идем, мол, ко мне, выпьем. А его жены не было дома, ну, он выпил, ушел домой. Так она, когда домой вернулась, меня всю ночь кляла. Зачем я ему выпить поднес?! Вот такие стали люди! А он мне двоюродный брат, родня. Раньше-то соседи были как-то больше доступны друг другу. А то разве как сейчас? Сейчас никаких соседов нет! Никакого сейчас разговору нет! Друг от дружки сейчас воруют и крадут, и боятся друг дружку, а тогда не боялись. Вот тогда были гулянки! Как вот, от нас и до самой Любы Шишкиной всех приглашали в одну компанию. Как зарядят, твою ж мать! Вот тут два стола стоят, и вон там тоже два стола стоят. Плясали! У меня были тогда пчелы. Бабушка нальет меда в чашки, а они медом пятки смажут и по столу пляшут. Это для куражу! Да и пятки липнут

6 Пушкин А.С. (1981) Собрание сочинений в 10 томах. Т. 6. «О втором томе "Истории русского парода" Н.А. Полевого». М.: Правда. С. 324. 
к столу, шум, гром. Это все было уже при колхозе. И до войны так было, и после войны. Люди тогда дружнее жили. Да, ругались, воевали, бывало. Всякая причина была. Чай, смерть найдет причину. Да, вот я тебе говорил: меня брат постриг, я ему налил, а его жена на меня пошла копной - ты, мол, его затравил! Страмит меня! Да, чай, у него своя голова на плечах есть. Если я не хочу, затрави меня, примерно. Соседи раньше лучше были, не как сейчас. Куды ни пойдешь, отказу никакого нет. А сейчас, тур твою мать, все прячут друг от дружки. Вот, слушай-ка. Вот, раньше, я помню, я еще небольшой был. Вот, где сейчас Тонька Тырышкина живет, за ней, там, еще один дом там был, Растегаевы там жили. И он по зимам все время к нам ходил, делать-то в это время не хрена было. Постелят тулупы на пол, в тулупах они ходили. Постелят они тулуп, сидят все на полу, курят, рассказывают про эту заваруху, про семнадцатый год. Припасут тыквенных семечек, лузгают. А пить - не пили совсем! Так что, вот, раньше жили! И ходили друг к другу и не ругались ни хрена! А сейчас - “гав-гав-гав, гав-гав-гав”. Одна ругань! Да, куда это жизньто повернула, даже и не знаю. Не знай, не знай! И вот вся эта жизня, вся она на нашем веку изменилась, все это на нашем веку произошло, все на нашей памяти. И, тур твою мать, сколько голодовок было! Сколько войн!».

Чем примечателен этот фрагмент нарратива? Его тремя последними строчками: так обычно выглядит дискурс крестьянской историософии. В ней отсутствует какая бы то ни было размечающая аналитика; здесь нет рассуждений, только констатирующая фиксация, видение во времени. Это явственная примета натуральных, «неиспорченных рефлексирующим интеллектом», крестьянских дискурсивных форматов. Последние удивительным образом соотносятся с первым тезисом «Логико-философского трактата» Людвига Витгенштейна7 “Die Welt ist alles, was der Fall ist” (принятый регулярный перевод «Мир есть все то, что имеет место»). В.В. Бибихин в книге «Витгенштейн: смена аспекта» объясняет и переводит этот тезис иначе - «мир есть то, что выпало». Вот аналитический подступ В.В. Бибихина к этому варианту перевода: «Наше видение мира <..> плавно переходит в ведение и ведание. Мы видим мир так, что сразу и ведаем о нем, поэтому ведаем им, делая его вольно или невольно таким, каким его увидели. Мир есть то, что выпало. Не надо добавлять “нам”. Мы не знаем, никогда не узнаем и не имеем никаких средств видеть и ведать мир иначе, чем как он увиден нами» [Бибихин 2005, с. 121]. И полуграмотный краснореченский мельник (он же и валяльщик, и бондарь, и печник) Иван Цаплин ведает, что «жизнь-то повернула», но не знает куда - «не знай, не знай!», так уж выпало. Натуральная органика дискурса крестьянской меры мира звучит здесь взволнованно и сокрушенно.

«У нас по зимам тут все снегом заметат, не пройдешь, не пролезешь. Хорошо - тут, за нами, у речки, мельница стоит: все-таки чистиют, народ-то едет молоть. Ну, теперь-то не молоть, а дробленку делать. Муку-то уж на ней не смелешь таперя. А ты знаешь, почему? Верхний камень тонкий. А зерно, когда попадает на стакан, его вон туды откидывает, и оно валится вниз, напрямую. У меня камень верхний уже тонкий стал, сносился уж. А ты знаешь, куды я ездил, за камнем-то? В Дергачи, на тот берег Волги, из Дергачей камень приволок, и не один, а два камня. Один-то потом раскололся, а другой остался.

7 Витгенштейн Л. (2017) Логико-философский трактат. М.: Канон+. 
Они хорошие, обработанные, как хрусталь, камни-то. А как говорят - нижнийто камень перемалывает верхний. Почему это говорят, знаешь? Жена-то мужа перебарывает! Так и камень (смеется). Ты понял меня? Нижний-то у меня камень толстый. А верхний - тонкий, вот зерно из-под него и вылетает. Сработался. Да мне и этого хватит до смерти (смеется)! А вот я помру, мельницу растащат и сожгут. Я, вот, председателю говорю: “Делай, покуда я жив! Обделывай мельницу-то! Я-то на ней работать не буду, так ведь? Но ты ее сделай при мне, а то ведь без меня ее никто не соберет". Ну, он сита привез новые, хорошие, но делать некому, не дает людей. Показать тебе эти сита? Сейчас покажу (npuносит материал). Видишь, как чистый шелк! Вот, когда у меня была дочь, Маруська, маленькая, я тоже купил сита, все для мельницы обделал, а маленько материалу-то осталось. Ну, мы ей из него школьную форму-то и сшили. Все сказали: “Ни хрена себе! Дочь-то мельникова в чем ходит”. А этот материал не мнется, стоймя стоит! Красивая у Марусеньки моей была школьная форма».

\section{Заключение}

Здесь запись заканчивается. Что остается после того, как выслушана эта повесть? То, что мир крестьянина событийно довольно узок, он имеет сложноподчиненную конструкцию, натянутую на некий стержень. И этот стержень - отобранные временем, сглаженные до технологического блеска практики использования ближайшей среды для поддержания вращения жизни. Вращения однообразного, приевшегося, но в сущности животворного. Иван Цаплин, рассказывая свою повесть, постоянно, охотно и умело совершает некие полноцветные живые прививки к древу собственной жизни и простодушно любуется ими. А порой недоуменно почесывает в затылке: как же это так вышло? Как выпало? Дискурсивная манера Ивана Цаплина внушает, что повседневная крестьянская жизнь - это некие анонимные правила, пренебрежение которыми сообщает жизненному порядку произвольность, неосновательность, несерьезность и рискованность. Но в то же время становится понятно, что и без правил жить вполне можно. Надо только слегка ухитриться и приспособиться, но не специально, после натужного раздумья, а небрежно и легко, полагаясь на обстоятельства, которые в деревенском социальном пространстве упаковываются в одну и ту же стандартную схему, в народный обычай. Крестьянская жизнь в такого рода дискурсивных практиках - это развернутое фольклорное происшествие, и серьезное, и игровое, подытоживаемое обычно диалектическим диагнозом - «и смех, и грех». В этой жизни есть место и труду, и лукавству, и воровству, и самоотвержению, и мистике, и удальству. Захват деревенской повседневности и сплошная вовлеченность Ивана Цаплина в однообразные мизансцены крестьянского бытия - все это вмещено в пространство его слова, зафиксированного на диктофонной ленте.

Дискурсы крестьянской жизни лишь изредка и, как правило, вынужденно, когда сельских людей об этом специально расспрашивают, пробуют разместить в своих форматах сколько-нибудь развернутый разбор причин и факторов «скверности» либо «славности» крестьянского повседневного существования, от таких разговоров обычно решительно отнекиваются. Они даже имеют специальные на- 
звания - «рассусоливать», «растабарывать». Такое отталкивание - не беззаботность и не равнодушие, это знак терпеливости и привычной нечувствительности к жизненной черно-белой чересполосице. Это и эффект от индукции, наведенной на мир крестьянского слова упорядоченностью циклического земледельческого бытия, элементарной прочностью порядка вещей и трудов, разрушение которых (коллективизация, выселение «неперспективок») - жизненная драма. Это и опасливое избегание заносчивой, не допускающей прекословий, распорядительности. Похожее настроение проявляется и в пословичной афористике - «от добра добра не ищут»; «не буди лихо, пока оно тихо»; «кто меньше толкует, тот меньше тоскует». Подобного рода настроение широко разлито и в дискурсах корневых крестьянских миров, тех сельских сообществ, в которых еще жива память о деревенской общине, когда в систематической обязательной установке были и сельские сходы, и послеуборочные заботы о содержании и наполненности страховых мирских амбаров, и общие работы по чистке речек, родников, окрестных лесов, и удобрение сенокосов, и ежегодный уход за оврагами.

Перейдет ли все это в будущие крестьянские миры или же это знак безвозвратно минувшей жизни? Если суммировать выводы ученых (демографов, социальных географов, специалистов по социологии села), обратиться к собственным наблюдениям, можно убедиться, что деревня как пространство традиционного крестьянского природопользования постепенно исчезает. На ее место приходят новые формы ведения хозяйства, вырастают и поднимаются новые люди, появляются современные хозяйственно-экономические практики, возникают и выговариваются иные дискурсы. Сегодняшняя деревня - зона смены темпов социального времени, место реорганизации пространств существования. Этот процесс идет противоречиво, он и удручает, и обнадеживает. Поэтому важно слушать свидетельства людей, к нему причастных, его наблюдающих, производящих новые дискурсивные форматы, где в очередной раз происходит обустройство мира.

\section{Литература}

Бибихин В.В. (2005) Витгенштейн: смена аспекта. М.: Институт философии, теологии и истории св. Фомы.

Бибихин В.В. (2009) Чтение философии. СПб.: Наука.

В Саратове фермеры поговорили с Медведевым простым крестьянским языком (2016) // Информационное агентство «Регион 64» // https://sarnovosti.ru/news.php?ID=43154

Демьянков В.3. (2007) Текст и дискурс как термины и как слова обыденного языка // IV Международная научная конференция «Язык, культура, общество». М.: Московский институт иностранных языков; Российская академия лингвистических наук; Институт языкознания РАН; «Вопросы филологии». С. 86-95.

Дискурсология - словарь терминов, понятий и концептов (2009) // Международная Академия Дискурс Исследований // http://madipi.ru/index.php?option=com_content\&view= article\&id $=113 \% 3 \mathrm{~A}-1 \mathrm{r} \&$ catid $=136 \% 3 \mathrm{~A}--$-lr\&limitstart $=1$

Палиевский П.В. (1979) Мировое значение Шолохова // Палиевский П.В. Литература и теория. М.: Сов. Россия. С. 272-285.

Фуко М. (1996) Порядок дискурса // Фуко М. Воля к истине: по ту сторону знания, власти и сексуальности. М.: Касталь. С. 47-96.

Redfield R. (1956) Peasant Society and Culture, Chicago: The University of Chicago Press. 


\title{
The Oral Stories of Peasants: an Exercise in Discursive Reading
}

\author{
V. VINOGRADSKIY*
}

\begin{abstract}
*Valeriy Vinogradskiy - Doctor of Science in Philosophy, Professor, Leading Researcher, Russian Presidential Academy of National Economy and Public Administration, RANEPA. Address: 82, Prospect Vernadskogo, Moscow, 119571, Russian Federation. E-mail: vgrape47@yandex.ru
\end{abstract}

Citation: Vinogradskiy V. (2018) The Oral Stories of Peasants: an Exercise in Discursive Reading. Mir Rossii, vol.27, no 1, pp. 90-113 (in Russian). DOI: 10.17323/1811-038X-2018-27-1-90-113

\begin{abstract}
How does the routine life of the peasantry reveal itself in its discoursive dimension? What are its specifics features? Can the rural world be understoond and recreated simply by listening to the genuine speech of peasants? What can researchers learn from a systematic observation of peasant discoursive practices? This article presents a discoursive analysis of a long narrative told by an old rural miller recorded during the First Field Peasantry Project supervised by Theodore Shanin. The discoursive practices of this peasant reveal that even though his life is very limited in terms of remarkable events it has a very complex structure and organization. It is structured around a firm nexus of life sustaining practices which maintain his organic existence in the surrounding environment and which have evolved over his entire life. In telling the story of his life, monotounous and full of simple routines, the miller very skillfully and willingly injects a few lively episodes which add several interesting shades to his personal biography and which he innocently and sincerely enjoys. The discoursive manner of this peasant tells us that the everyday life of a peasant consists of a set of anonymous rules, the neglect of which may bring disorder and randomness. Yet following these rules is not strictly necessary: one could easily adapt and find a way around them for different situations, but doing so does not require a peasant to be intentional or rational. Rather one should follow the circumstances which in the social space of a peasant are usually wrapped in a common transhistoric and relatively standard framework - folk customs.
\end{abstract}

Key words: discourse, discursive practices, style, oral history, peasant worlds, sociology of the village, rural everyday life, the evolution of discursive practices

\section{References}

Bibihin V.V. (2005) Wittgenstein: smena aspekta [Wittgenstein: A Change of Aspect], Moscow: Institut filosofii, teologii i istorii sv. Fomy.

Bibihin V.V. (2009) Chtenie filosofii [Reading of Philosophy], Saint Petersburg: Nauka. 
Dem'yankov V.Z. (2007) Tekst i diskurs kak terminy i kak slova obydennogo yazyka [A Text and a Discourse as Terms and as Words of an Ordinary Language]. IV Mezhdunarodnaya nauchnaya konferenciya «Yazyk, kul'tura, obshchestvo». Moskva, 27-30 sentyabrya 2007 g.: Plenarnye doklady [IV International Scientific Conference "Language, Culture, Society"], Moscow: Moskovskij institut inostrannykh yazykov; Rossijskaya akademiya lingvisticheskikh nauk; Institut yazykoznaniya RAN; «Voprosy filologii», pp. 86-95.

Diskursologiya - slovar' terminov, ponyatij i kontseptov [Discourse Studies - a Glossary of Terms, Notions and Concepts]. Mezhdunarodnaya Akademiya Diskurs Issledovanij [International Academy Of Discourse Research]. Available at: http://madipi.ru/index.php?option= com_content\&view=article\&id=113\%3A-1r\&catid=136\%3A--1r\&limitstart=1, accessed 31 October 2017.

Foucault M. (1996) Poryadok diskursa [The Order of Discourse]. Foucault M. Volya k istine: po tu storonu znaniya, vlasti i seksual'nosti [The Will to the Truth: Beyond Knowledge, Power and Sexuality], Moscow, Kastal', pp. 47-96.

Palievskij P.V. (1979) Mirovoe znachenie Sholokhova [Global Significance of Sholokhov]. Palievskij P.V. Literatura $i$ teoriya [Literature and Theory], Moscow: Sov. Rossiya, pp. 274-275.

Redfield R. (1956) Peasant Society and Culture, Chicago: The University of Chicago Press.

V Saratove fermery pogovorili s Medvedevym prostym krest'yanskim yazykom (2016) [Farmers Spoke in Plane Peasant Language to Medvev in Saratov]. InformAgency "Region64". Available at: https://sarnovosti.ru/news.php?ID=43154, accessed 31 October 2017. 